УДК 635.96:632.4:632.7(471.63)

DOI 10.30679/2219-5335-2019-4-58-166-179

ФОРМИРОВАНИЕ АДАПТИВНОГО СОРТИМЕНТА ГИБРИДНОГО ТРАВЯНИСТОГО ГИБИСКУСА (HIBISCUS X MOSCHETOUS L.)

В УСЛОВИЯХ ЮЖНОГО САДОВОДСТВА

Тыщенко Евгения Леонидовна канд. с.-х. наук ст. научный сотрудник лаборатории сортоизучения и селекции садовых культур e-mail: garden_centr@mail.ru

Мищенко Ирина Григорьевна младший научный сотрудник лаборатории защиты плодовых и ягодных культур e-mail: plantprotecshion@yandex.ru

Кащиц Юлия Петровна аспирант мл. научный сотрудник лаборатории защиты плодовых и ягодных культур

Федеральное государственное бюджетное научное учреждение «Северо-Кавказский федеральный научный иентр садоводства, виноградарства, виноделия», Краснодар, Россия

В условиях южного садоводства изучен адаптивный потенциал 12 интродуцированных сортов (Hibiscus х moscheutos L.) Cranberry Crush, Fantasia, Fireball, Jazzberry Jam, Kopper King, Old Yella, Plam Crasy, Royal Gems, Robert Fleming, Summer Storm, Pepermint Shnaps, Heartthrob. Дана оценка устойчивости интродуцированных сортов к комплексу неблагоприятных летних стресс-факторов (высокие летние температуры, достигающие $+37^{\circ} \mathrm{C}$ и выше, дефицит
UDC 635.96:632.4:632.7(471.63)

DOI 10.30679/2219-5335-2019-4-58-166-179

\section{FORMATION OF ADAPTIVE ASSORTMENT OF HYBRID HERBACEOUS HIBISCUS (HIBISCUS X MOSCHETOUS L.) UNDER CONDITIONS OF SOUTHERN GARDENING}

Tyshchenko Evgenia Leonidovna Cand. Agr. Sci.

Senior Research Associate of Laboratory of Variety's study and Breeding of Garden crops e-mail: garden_centr@mail.ru

Mishchenko Irina Grigoryevna Junior Research Associate of Laboratory of Fruit and Berry crops Protection e-mail: plantprotecshion@yandex.ru

Kashchits Yulia Petrovna Post Graduate Student Junior Research Associate of Laboratory of Fruit and Berry crops Protection

\section{Federal State}

Budget Scientific Institution "North Caucasian Federal Scientific Center of Horticulture, Viticulture, Wine-making», Krasnodar, Russia

Under the conditions of Southern gardening, the adaptive potential of 12 introduced varieties (Hibiscus $x$ moscheutos L.): Cranberry Crush, Fantasia, Fireball, Jazzberry Jam, Kopper King, Old Yella, Plam Crasy, Royal Gems, Robert Fleming, Summer Storm, Pepermint Shnaps, Heartthrob was studied.

The stability of introduced varieties to the complex of unfavorable summer stress factors (high summer temperatures reaching $+37^{\circ} \mathrm{C}$ and above, deficiency 
воздушной и почвенной влаги, суховейные явления, повышенная инсоляция).

Выделены наиболее устойчивые сорта: Peppermint Schnapps, Fantasia, Fareball, Jazzberry Jam, Summer Storm устойчивость на уровне 4-5 баллов. Для сортов Fantasia u Pepermint Shnaps характерна плотная восковая кутикула листивой пластинки, которая обусловливает их повышенную засухоустойчивость. Сорта: Royal Gems, Plum Crasy, Robert Fleming не жаростойкие - хуже других переносят сухой жаркий период, устойчивость - 3 балла. У этих сортов в летний период при засухе сокращается период цветения, снижается размер цветка, листья теряют тургор. У сортов Cranberry Crush u Heartthrob наблюдается усыхание и осыпание бутонов. На некоторых растениях выявлены признаки заболеваний: Alternaria sp., Colletotrichum hibisci Poll., Fusarium equiseti (Corda) Sacc, Phytophthora sp. На растениях сорта Kopper King зафиксированы симптомы поражения вирусного происхождения. На отдельных растениях обнаружены вредители: Heliothis armigera L, Autographa gamma L., Metcalfa pruinosa Say., Tetranychus sp. Полученные данные указывают на необходимость разработки защитных мероприятий при возделывании Hibiscus х moscheutos L. в условиях южного садоводства России.

Ключевые слова: HIBISCUS X MOSCHETOUS L., АДАПТИВНОСТЬ, СТРЕСС-ФАКТОРЫ, ПАТОГЕНЫ, ЮЖНОЕ САДОВОДСТВО of air and soil moisture, dry-water phenomena, increased insolation) is estimated. The most stable varieties are selected: Peppermint Schnapps, Fantasia, Fireball, Jazzberry Jam, Summer Storm - stability at the level of 4-5 points. For varieties Fantasia and Peppermint Schnapps distinctive thick waxy cuticle of the leaf, which causes their increased drought tolerance, is topical. The varieties of Royal Gems, Plum Crazy, Robert Fleming are non-resistant, they worse than others tolerate to dry hot period, their stability is 3 points. These varieties in the summer with drought reduced the flowering period, the flower size, he leaves lose turgor. It is observed the desiccation and shedding of buds for the varieties of Cranberry Crush and Heartthrob. Some plants showed the signs of the disease: Alternaria sp., Colletotrichum hibisci Poll., Fusarium equiseti (Corda) Sacc, Phytophthora sp. On the plants of Kopper King, $\mathrm{t}$ he symptoms of defeat of viral origin are noted. On some plants the vermins are observed - Heliothis armigera L, Autographa gamma L., Metcalfa pruinosa Say., Tetranychus sp. The obtained data indicate the need for the development of protective measures in the process of cultivation of Hibiscus $x$ moscheutos L. in the Southern horticulture of Russia.

Key words: HIBISCUS X MOSCHETOUS L., ADAPTABILITY, STRESS FACTORS, PATHOGENS, SOUTHERN GARDENING

Введение. Среди цветочных многолетних культур довольно мало растений, характеризующихся продолжительным цветением (4-5 недель и более). Поэтому при создании ландшафтных композиций декоративные многолетники в качестве доминанты используются редко. На юге России, особенно на территориях санаторно-курортной зоны, в настоящее время 
Плодоводство и виноградарство Юга России № 58(04), 2019 г.

востребованы декоративные растения с такими ценными хозяйственно биологическими признаками как яркая разнообразная окраска цветков, обильное продолжительное цветение, не очень сложная агротехника, устойчивость к заболеваниям, вредителям и стресс-факторам абиотического происхождения. Гибридный травянистый гибискус (Hibiscus x moscheutos L.) по многим показателям отвечает этим требованиям.

Современные сорта травянистого гибискуса - это результат реализации сложной гибридизации, в том числе с участием природных видов H.coccineus, H.militaris, H.moscheutos, H.grandiflorus и других $[1,2]$. Полученные генотипы гибридного гибискуса отличаются большим разнообразием по морфологическим признакам [3, 4]. В связи с тем, что сорта получены в регионах с разными природно-климатическими условиями, при интродукции в зоне южного садоводства культивары адаптируются поразному и варьируют в проявлении ценных декоративных признаков.

Гибридные травянистые гибискусы отличаются ярким эффектным и продолжительным цветением (от 2-3 недель до 3,5 месяцев) $[5,6,7,8]$. На юге России цветение гибискусов начинается с I декады июля и продолжается, у отдельных сортов, до середины октября.

С помощью комбинации разных сортов можно сформировать «конвейер» цветения гибридного гибискуса в ландшафтных композициях или клумбах (продолжительность до 4-4,5 месяцев). Таких декоративных многолетников, цветущих продолжительное время во второй половине вегетационного периода, очень мало $[3,8,9]$. В связи с этим, гибридный травянистый гибискус представляет значительный интерес для декоративного садоводства на юге России.

Цель настоящих исследований - сформировать сортимент гибридного травянистого гибискуса, адаптивного к проявлению стрессфакторов биотического и абиотического происхождения в условиях южного садоводства. 
Объекты и методы исследований. В исследование включено 12 перспективных сортов гибискуса из коллекции ФГБНУ «СевероКавказский федеральный научный центр садоводства, виноградарства, виноделия» (г. Краснодар): Cranberry Crush, Fantasia, Fireball, Jazzberry Jam, Kopper King, Old Yella, Plam Crasy, Royal Gems, Robert Fleming, Summer Storm, Pepermint Shnaps, Heartthrob.

Коллекция гибридного травянистого гибискуса выращивается без капельного орошения, в междурядьях - задернение естественно-растущих трав, в ряду - мульчирование корой лиственницы слоем 10-12 см. Оценку адаптивного потенциала интродуцированных сортов гибридного травянистого гибискуса проводили с учетом общепринятых методик при конкурсном сортоиспытании $[8,10,11,12,13,14]$.

Приборное обеспечение: микроскоп биологический тринокулярный XSZ-148E; видеоокуляр ДСМ-130.

обсуждение результатов. На юге России культивируемые декоративные растения подвержены воздействию стресс-факторов абиотического характера. На растения гибридного гибискуса наибольшее негативное влияние оказывают высокие летние температуры, достигающие $+37^{\circ} \mathrm{C}$ и выше на фоне дефицита воздушной и почвенной влаги, суховейные явления, повышенная инсоляция. Этот комплекс абиотических стрессоров летнего периода в наибольшей степени проявляется в июле-августе и совпадает с фенофазой «массовое цветение»у многих сортов травянистого гибискуса, что значительно снижает декоративные признаки этих растений. Наибольшую ценность представляют сорта, проявляющие высокую устойчивость к вышеперечисленным негативным факторам.

По результатам наблюдений за сортами после воздействия негативных погодных условий летнего периода выделены наиболее устойчивые культивары (табл.). 
Устойчивость сортов гибридного травянистого гибискуса (Hibiscus $x$ moscheutos L.) к комплексу неблагоприятных летних стресс-факторов, балл (июль-август 2016-2018 гг.).

\begin{tabular}{|c|c|c|}
\hline Сорт & $\begin{array}{c}\text { Устойчивость } \\
\text { по 5-балльной } \\
\text { шкале }\end{array}$ & $\begin{array}{c}\text { Примечание } \\
\text { (наиболее характерные повреждения } \\
\text { при воздействии стресса) }\end{array}$ \\
\hline Cranberry Crush & $3-4$ & Усыхание бутонов \\
\hline Fantasia & $4-5$ & Снижается размер цветка \\
\hline Fireball & $4-5$ & Снижается размер цветка \\
\hline Jazzberry Jam & $4-5$ & Сокращается период цветения \\
\hline Heartthrob & $3-4$ & $\begin{array}{l}\text { Потеря тургора листьев и лепестков } \\
\text { цветка }\end{array}$ \\
\hline Kopper King & 4 & Снижается размера цветка \\
\hline Old Yella & $3-4$ & $\begin{array}{l}\text { Цветение отсутствует } \\
\text { или резко снижается размер цветка }\end{array}$ \\
\hline Peppermint Schnapps & 5 & Сокращается период цветения \\
\hline Plum Crasy & 3 & Цветение отсутствует \\
\hline Royal Gems & 3 & $\begin{array}{l}\text { Снижается размер цветка, } \\
\text { сокращается период цветения }\end{array}$ \\
\hline Robert Fleming & 3 & $\begin{array}{l}\text { Цветение отсутствует, усыхают } \\
\text { бутоны, потеря тургора листьев }\end{array}$ \\
\hline Summer Storm & $4-5$ & Снижается размер цветка \\
\hline
\end{tabular}

Как видно из таблицы интродуцированные сорта по-разному реагируют на стрессоры абиотического происхождения. При высоких температурах воздуха и длительной засухе чаще всего у растений гибискуса снижается размер цветка или прекращается цветение. Такая реакция наблюдается у сортов: Old Yella, Plum Crasy, Royal Gems, Robert Fleming.

Усыхание и осыпание бутонов наблюдается у сортов: Cranberry Crush и Heartthrob (рис. 1). Низкая засухоустойчивость характерна для сорта Robert Fleming. После 10-12 дней засухи при высокой температуре воздуха (+30 ${ }^{\circ} \mathrm{C}$ и выше) наблюдается сильная потеря тургора у листового аппарата (рис. 2). 


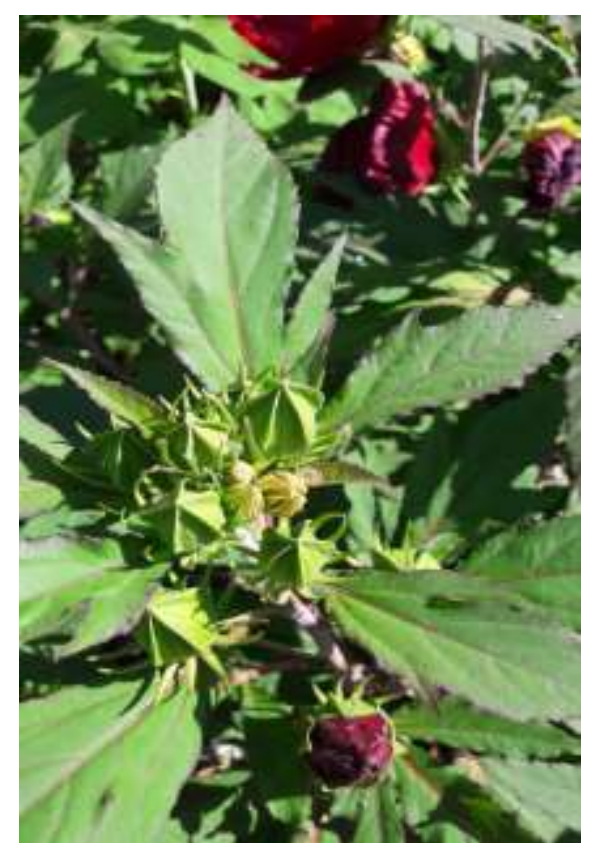

Cranberry Crush

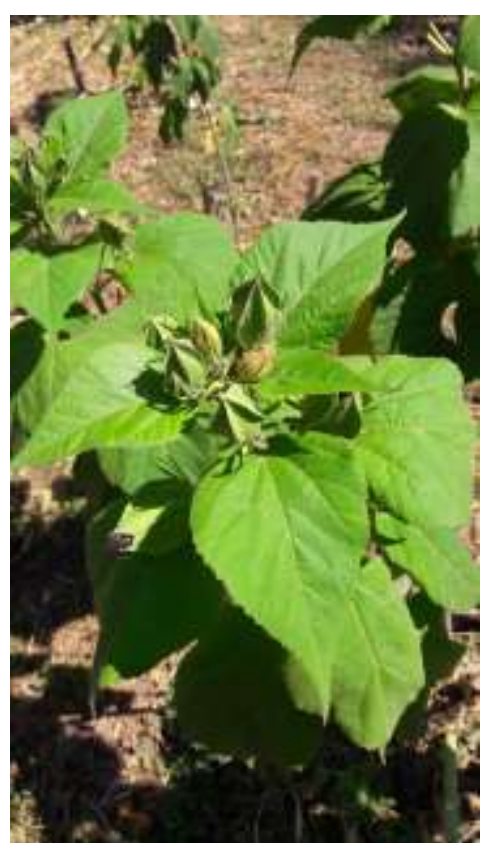

Heartthrob

Рис. 1. Усыхание бутонов у сортов гибридного гибискуса в жаркий, сухой период (июнь-август)

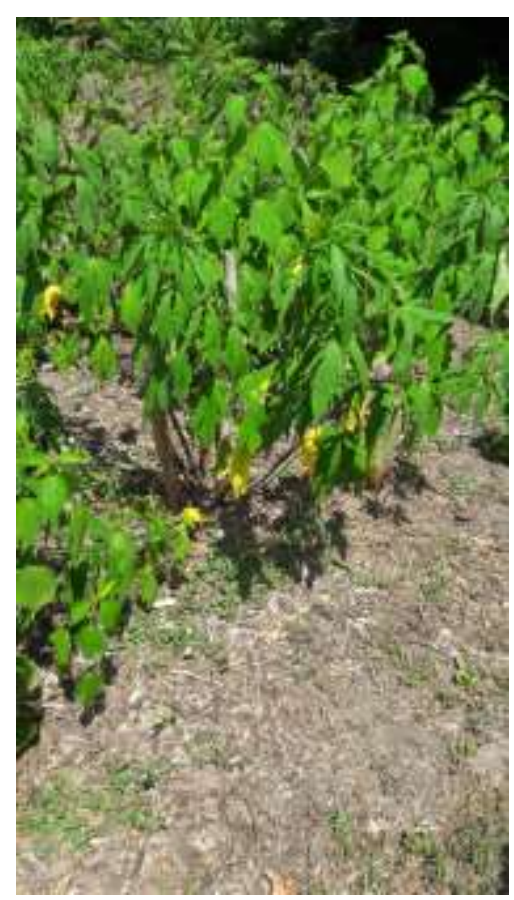

Рис. 2. Потеря тургора у листьев сорта Robert Fleming в жару, июль 2018 г.

У сортов Fantasia, Fireball, Jazzberry Jam, Summer Storm, Kopper King реакция на комплекс стрессоров летнего периода проявляется в основном в 
снижении размеров цветка. Так, у сорта Fireball максимальный диаметр цветка составляет 27-29 см, а при наступлении жары - 22-23 см.

Следует отметить, что при этом декоративность цветков и растения в целом остаётся достаточно высокой. По нашим наблюдениям, высокой адаптивностью к условиям летнего периода на юге России выделяется сорт Peppermint Schnapps (5 баллов), который можно рассматривать как источник засухоустойчивости и жаростойкости при проведении селекционных работ (рис. 3).

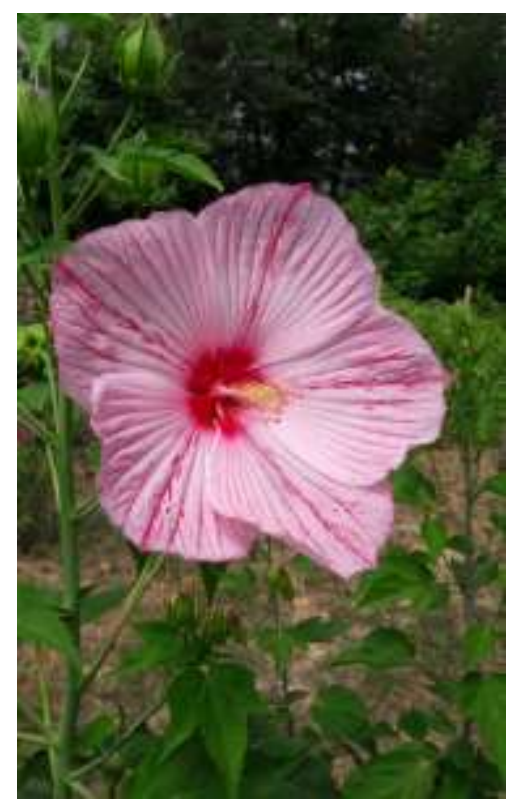

Рис. 3. Сорт Peppermint Schnapps - источник засухоустойчивости и жаростойкости, июль, 2018 г.

Повышенную засухоустойчивость также проявляют сорта: Fantasia, Fireball, Jazzberry Jam, Summer Storm (4-5 баллов). У этих сортов в период засухи перерыв в цветении минимальный и при поливе цветение продолжается до 2-2,5 месяцев. Сорта Jazzberry Jam, Fantasia хорошо и обильно продолжают цветение в осенние месяцы - сентябрь-октябрь (рис. 4).

Следует отметить, что устойчивость к высоким температурам и дефициту почвенной и воздушной влаги характерна для сортов, у которых листовая пластинка имеет характерную плотную восковую кутикулу (Fantasia, Peppermint Schnapps) (рис. 5). 


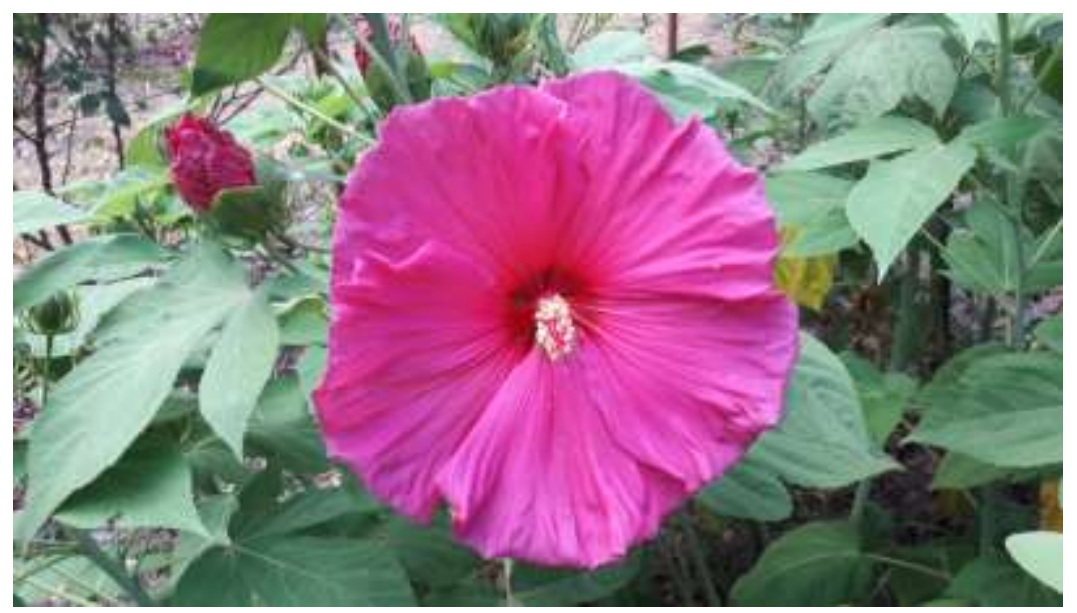

Рис. 4. Осеннее цветение сорта Jazzberry Jam, октябрь, 2018 г.

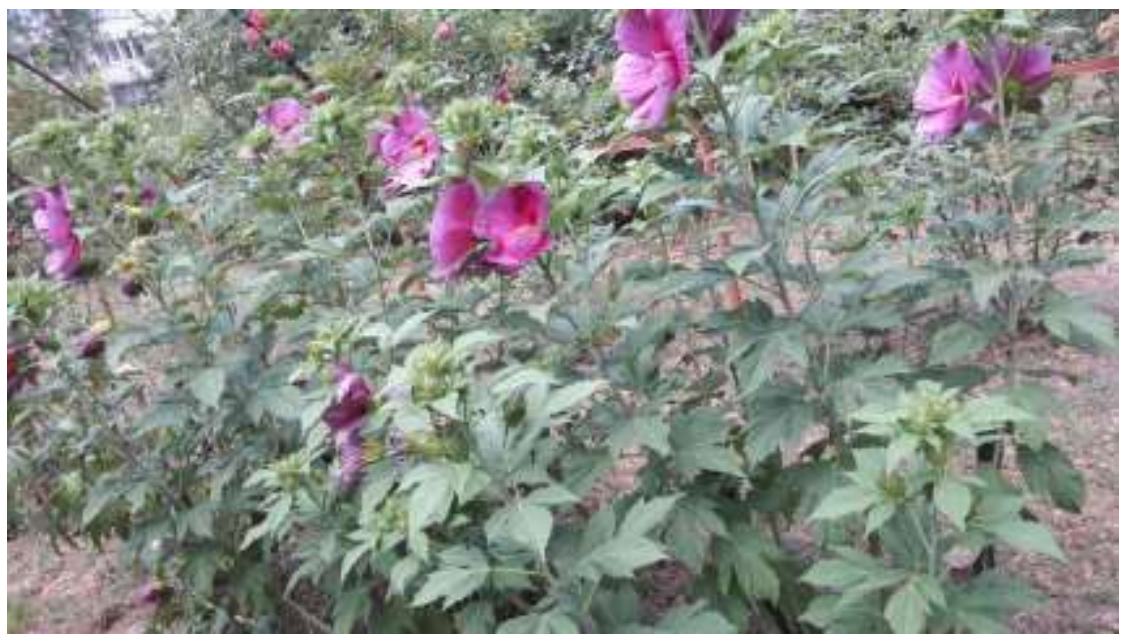

Рис. 5. Устойчивость листового аппарата сорта Fantasia в летний период, июль 2018 г.

Кроме абиотических стресс-факторов интродуценты испытывают прессинг со стороны патогенов различного происхождения. По нашим наблюдениям культура гибридного травянистого гибискуса достаточно устойчива к повреждению вредителями и поражению патогенными грибами и вирусами. Однако с расширением коллекции и формированием разнообразия генотипов гибридного гибискуса проявляются симптомы заболеваний на отдельных растениях. 
Плодоводство и виноградарство Юга России № 58(04), 2019 г.

По результатам проводимого мониторинга санитарного состояния коллекции выявлен ряд заболеваний, которые встречаются пока на единичных растениях, но это указывает на потенциальную поражаемость этой культуры в условиях южного садоводства России.

В конце августа на листьях некоторых сортов (Robert Fleming, Royal Gems, Hearthrob) обнаружены признаки поражения грибами рода Alternaria sp. и Colletotrichum hibisci Poll [9].

В 2017 году на растениях сорта Kopper King обнаружены симптомы поражения вирусного происхождения (рис. 6).
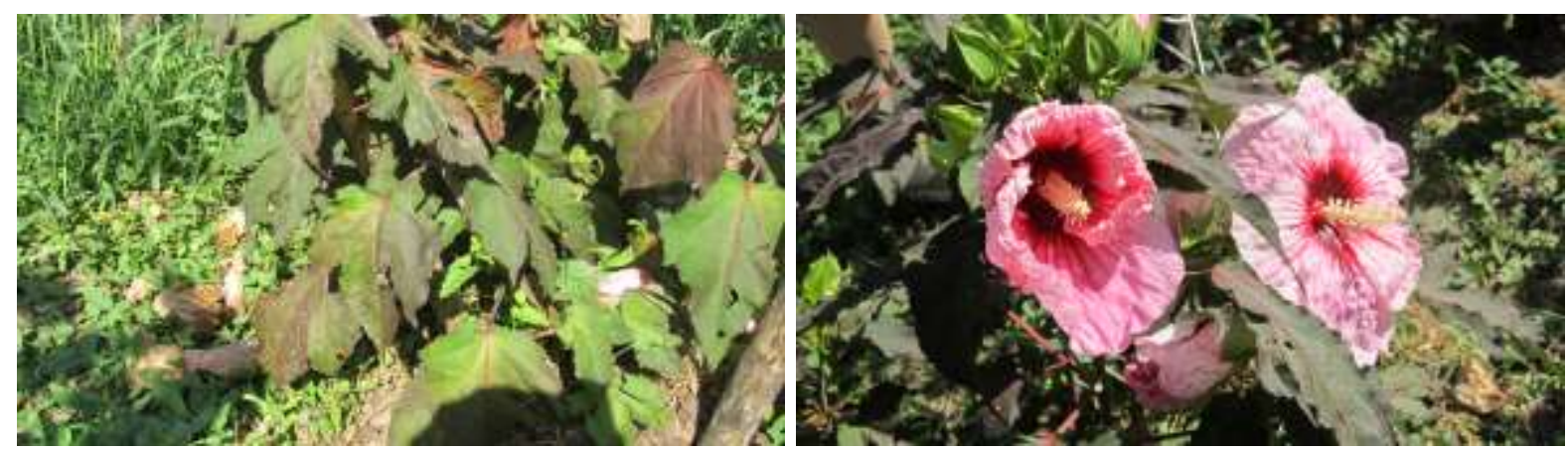

Рис. 6. Симптомы поражения вирусного происхождения растений сорта Kopper King, август 2017 г.

Это факт поражения растений данным патогеном требует дальнейшего наблюдения и идентификации возбудителя. Изменение технологии выращивания культур, появление новых сортов, активный обмен посадочным материалом без надлежащего контроля их качества, изменение климата, нарушение фитосанитарных правил с попыткой истребления наиболее опасных вредных организмов посредством одностороннего интенсивного применения химических средств защиты растений приводят к активизации новых, ранее не имеющих существенного экономического значения болезней.

В 2018 году на листьях отдельных растений гибридных форм травянистого гибискуса обнаружены возбудители фузариоза и фитофтороза (рис. 7, 8). 


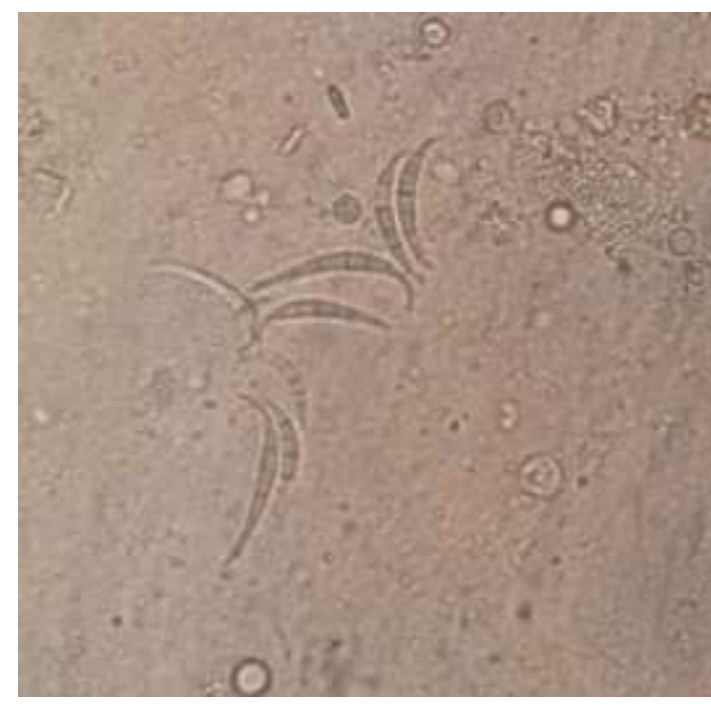

Рис. 7. Конидиальное спороношение возбудителя Fusarium eguiseti (Corda) Sacc

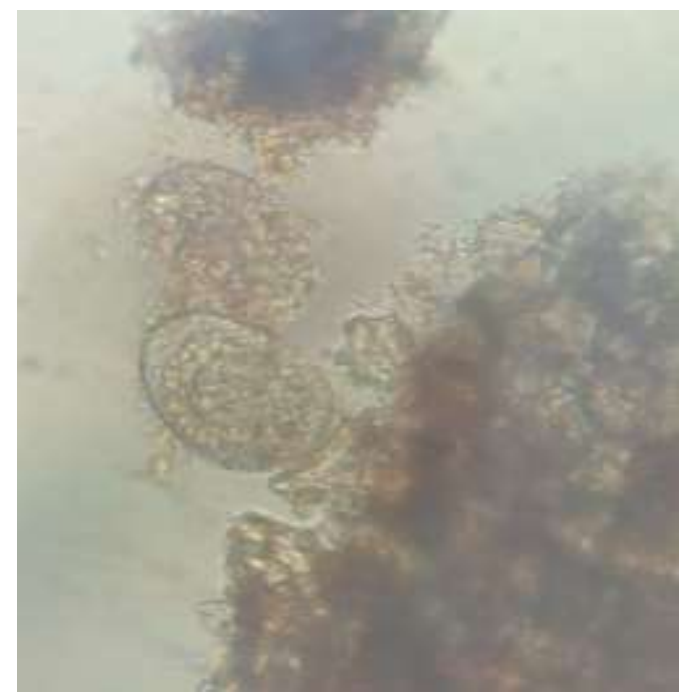

Рис. 8. Зооспорангии гриба рода Phytophthora sp.

Фузариоз - инфекционное заболевание растений (культурных и дикорастущих), вызываемое грибами рода Fusarium. Развитию болезни способствуют неблагоприятные условия содержания (резкие колебания температуры и влажности воздуха и почвы, недостаток почвенного питания, слишком плотная почва, переизбыток влаги), ослабляющие растение, повреждение насекомыми и др. Возбудители патогена наиболее активны при температуре около $+25{ }^{\circ} \mathrm{C}$, влажности воздуха около $90 \%$, они долго сохраняются в почве и на растительных остатках, попадая в растения через заражённую почву. Затем, по проводящим сосудам поднимаются в стебель и доходят до листьев. Нижние листья увядают, края остальных становятся водянистыми, а отдельные участки бледно-зелеными или светло-желтыми. Вскоре всё растение увядает и гибнет.

Заболевание в основном распространяется очагами. Наиболее восприимчивы к болезни ослабленные растения. Грибы - возбудители фузариозного увядания хорошо защищены от воздействия внешних факторов как в сапрофитной фазе своего развития в почве и на растительных остатках, так и находясь в сосудистой системе растений в период вегетации. 
Они обладают хорошей экологической пластичностью и легко приспосабливаются к новым экологическим условиям $[15,16,17,18,19]$.

Мицелий гриба фитофторы, имеющий вид белой паутины, развивается в тканях растений. Зооспорангиеносцы простые или слегка неправильно разветвленные, похожие на вегетативные гифы, выходят, пронизывая эпидермис, по одиночке или пучками из устьиц. Зооспорангии на концах ответвлений яйцевидные или лимоновидные.

Кроме полового размножения спорами, эти грибы могут размножаться бесполым путем - конидиями. Споры фитофторы перезимовывают на растительных остатках, в почве. Из спор при благоприятных условиях (высокая температура и влажность) быстро развивается мицелий грибов. Споры могут давать начало мицелию грибов и на листьях, переходя от растения к растению. Необходимые условия быстрого развития этих грибов - температура воздуха выше 10 градусов и влажность выше 75 \% в течение более 2-3 суток. Интенсивное спорообразование начинается в ночное время при влажности около 90 \% (не ниже 76 \%) и температуре воздуха $+20{ }^{\circ} \mathrm{C}$. Сформировавшиеся конидии попадают в каплю воды, образуют зооспоры, прорастающие за 1-2 часа при температуре $+12{ }^{\circ} \mathrm{C}-+15^{\circ} \mathrm{C}$.

Дальнейшее развитие патогена и внедрение в ткани растений требует температуры $+20{ }^{\circ} \mathrm{C}-+24^{\circ} \mathrm{C}$. Активное развитие фитофтороза наблюдается в период чередования прохладных ночей и умерено теплых облачных дней. Капли дождя смывают споры гриба в почву, где они снова могут поражать новые растения, также после гибели растения-хозяина гриб снова попадает в почву. Существует ещё один путь распространения гриба - перенос ветром спор от источника заражения на большие расстояния [20].

Из вредителей обнаружены небольшие повреждения растений хлопковой совкой (Heliothis armigera L.), совкой-гаммой (Autographa gamma L.), восковой (мучнистой) цикадкой (Metcalfa pruinosa Say.), паутинным клещом (Tetranychus sp.) [9]. 
Плодоводство и виноградарство Юга России № 58(04), 2019 г.

Полученные данные свидетельствуют о необходимости постоянного мониторинга насаждений гибридного травянистого гибискуса на предмет оперативного выявления и устранения возможных патогенных организмов.

Bbыводы. Для успешного внедрения в практику зеленого строительства гибридного травянистого гибискуса необходимо использовать сорта, сочетающие в генотипе высокую адаптивность к стрессорам различного происхождения и ценные декоративные признаки.

По результатам наблюдений выделено несколько наиболее устойчивых сортов в условиях южного садоводства: Peppermint Schnapps, Fantasia, Fireball, Jazzberry Jam, Summer Storm. Эти культивары лучше других приспособлены к воздействию комплекса абиотических стрессоров летнего периода.

Выявлены потенциально опасные возбудители заболеваний изучаемой культуры: Alternaria sp., Colletotrichum hibisci Poll., Fusarium equiseti (Corda) Sacc, Phytophthora sp. Возможны поражения растений гибридного гибискуса патогенами вирусного происхождения, обнаружены повреждения следующими вредителями: Heliothis armigera L., Autographa gamma L., Metcalfa pruinosa Say., Tetranychus sp.

Полученные данные указывают на необходимость разработки защитных мероприятий в системе агротехнических приемов возделывания гибридного травянистого гибискуса.

\section{Литература}

1. Wise D.A. and Menzel M.Y. (1971) Genetic affinities of the North American species of Hibiscus sect. Trionum. Brittonia 23: 425-437.

2. Winters H.F. (1970) Our hardy Hibiscus species as ornamentalis. Econ.Bot. 24: $155-164$.

3. Тыщенко Е.Л. Морфометрические показатели перспективных сортов травянистого гибискуса (Hibiscus x moscheutos L) в связи с оценкой адаптивного потенциала в условиях центральной подзоны Краснодарского края [Электронный ресурс] // Плодоводство и виноградарство Юга России. 2018. № 54(6). С. 165-173. URL: http://journalkubansad.ru/pdf/18/06/16.pdf. DOU: 10.30679/2219-5335-2018-6-54-165-173 (дата обращения: 21.01.2019). 
4. Kuligowska K., Simonsen M., Lutken H., Muller R. and Christensen B. (2012) Breeding of Hibiscus rosa - sinensis for garden use in Denmark. Acta Hortic. 990: 235-242.

5. Lawton B.P. (2004) Hibiscus hardy and tropical plants for the garden. Timber Press: Portland, OR: p.160.

6. Warner R. and Erwin J. (2001) Variation in floral induction requirements of Hibiscus sp. J.Amer.Soc. Hort. Sci. 126: 262-268.

7. Warner R. and Erwin J. (2003) Effect of photoperiod and daily light integral on flowering of five Hibiscus sp. Sci. Hortic. 97: 341-351.

8. Залевская Е.М. Ритм развития гибридных гибискусов и опыт оценки их декоративных качеств и хозяйственно-биологических признаков // Интродукция и акклиматизация растений. Вып. 24. Ташкент, 1991. С. 36-41.

9. Тыщенко Е.Л., Тимкина Ю.В. Интродукция гибридного гибискуса на юге России // Субтропическое и декоративное садоводство: сб. научн. тр. ФГБНУ ВНИИЦиСК. Вып. 57. Сочи: ФГБНУ ВНИИЦиСК, 2016. С. 57-62.

10. Тыщенко Е.Л. Новые подходы к методологии оценки декоративных и хозяйственно-биологических признаков гибридного гибискуса // Субтропическое и декоративное садоводство: сб. научн. тр. ФГБНУ ВНИИЦиСК. Вып.62. Сочи: ФГБНУ ВНИИЦиСК, 2017. С.122-128.

11. Методика Государственного сортоиспытания сельскохозяйственных культур. Вып.6 (декоративные культуры). М.: Колос, 1968. 223с.

12. Методы экспериментальной микологии / под ред. В.И. Билай. Киев: Наукова думка, 1973. 240 с.

13. Наумов Н.А. Методы микологических и фитопатологических исследований. М., Л.: Сельхозгиз. 1997. 272 с.

14. Пидопличко Н.М. Грибы - паразиты культурных растений. Определитель. Пидопличко. Киев, 1977. Т. 2. 298 с.

15. Грушко Г.В., Линченко С.Н., Алешин Н.Е. Актуальные аспекты проблемы фузариоза колоса пшеницы и фузариотоксинов на Кубани // Фундаментальные исследования. 2005. № 2. С.7 4-75. URL: https:// fundamental-research.ru/ru/article/view?id= $\underline{5748}$

16. Якуба Г.В. Структура патогенного комплекса возбудителей микозов наземной части растений яблони в условиях изменения климата // Научные труды ГНУ СКЗНИИСиВ. Том 5. Краснодар: ГНУ СКЗНИИСиВ, 2014. С. 151-157.

17. Фузариоз зерновых культур / Т.Ю. Гагкаева, О.П. Гаврилова, М.М. Левитин [и др.]. // Защита и карантин растений. №5 (Приложение). 51 с.

18. Helgard, Kerrv, 1998. New Fusarium species and combinations within the Gibberella fujikuroi species complex. - Mycologia. - 90(3). p. 434-458.

19. Hassan N., Shimizu M., Hyakumachi M. (2014) Occurrence of root rot and vascular with diseases in Roselle (Hibiscus sabdariffa L.) in Upper Egypt / Naglaa Hassan, Masafumi Shimizu \& Mitsuro Yyakumachi Pages 66-72 / Received 19 Dec. 2013. Accepted 03 Feb. 2014, Published online: 19 Jun. 2018.

20. Brasier C. M. Phytophthora biodiversity: how many Phytophthora species are there? // Phytophthoras in Forests and Natural Ecosystems / Goheen E.M., Frankel S.J. (eds.). - Albany, CA, USA: USDA Forest Service, 2009. - P. 101-115.

\section{References}

1. Wise D.A. and Menzel M.Y. (1971) Genetic affinities of the North American species of Hibiscus sect. Trionum. Brittonia 23: 425-437.

2. Winters H.F. (1970) Our hardy Hibiscus species as ornamentalis. Econ.Bot. 24: $155-164$. 
3. Tyshchenko E.L. Morfometricheskie pokazateli perspektivnyh sortov travyanistogo gibiskusa (Hibiscus x moscheutos L) v svyazi s ocenkoj adaptivnogo potenciala v usloviyah central'noj podzony Krasnodarskogo kraya [Elektronnyj resurs] // Plodovodstvo $\mathrm{i}$ vinogradarstvo Yuga Rossii. 2018. № 54(6). S. 165-173. URL: http://journalkubansad.ru/pdf/18/06/16.pdf. DOU: 10.30679/2219-5335-2018-6-54-165-173 (data obrashcheniya: 21.01.2019).

4. Kuligowska K., Simonsen M., Lutken H., Muller R. and Christensen B. (2012) Breeding of Hibiscus rosa - sinensis for garden use in Den-mark. Acta Hortic. 990: 235-242.

5. Lawton B.P. (2004) Hibiscus hardy and tropical plants for the gar-den. Timber Press: Portland, OR: p.160.

6. Warner R. and Erwin J. (2001) Variation in floral induction requirements of Hibiscus sp. J.Amer.Soc. Hort. Sci. 126: 262-268.

7. Warner R. and Erwin J. (2003) Effect of photoperiod and daily light integral on flowering of five Hibiscus sp. Sci. Hortic. 97: 341-351.

8. Zalevskaya E.M. Ritm razvitiya gibridnyh gibiskusov i opyt ocenki ih dekorativnyh kachestv i hozyajstvenno-biologicheskih priznakov // Introdukciya i akklimatizaciya rastenij. Vyp. 24. Tashkent, 1991. S. 36-41.

9. Tyshchenko E.L., Timkina Yu.V. Introdukciya gibridnogo gibiskusa na yuge Rossii // Subtropicheskoe i dekorativnoe sadovodstvo: sb. nauchn. tr. FGBNU VNIICiSK. Vyp. 57. Sochi: FGBNU VNIICiSK, 2016. S. 57-62.

10. Tyshchenko E.L. Novye podhody k metodologii ocenki dekorativnyh i hozyajstvenno-biologicheskih priznakov gibridnogo gibiskusa // Subtropicheskoe i dekorativnoe sadovodstvo: sb. nauchn. tr. FGBNU VNIICiSK. Vyp.62. Sochi: FGBNU VNIICiSK, 2017. S.122-128.

11. Metodika Gosudarstvennogo sortoispytaniya sel'skohozyajstvennyh kul'tur. Vyp.6 (dekorativnye kul'tury). M.: Kolos, 1968. 223s.

12. Metody eksperimental'noj mikologii / pod red. V.I. Bilaj. Kiev: Naukova dumka, 1973. $240 \mathrm{~s}$.

13. Naumov N.A. Metody mikologicheskih i fitopatologicheskih issledovanij. M., L.: Sel'hozgiz. 1997. $272 \mathrm{~s}$.

14. Pidoplichko N.M. Griby - parazity kul'turnyh rastenij. Opredelitel'. Pidoplichko. Kiev, 1977. T. 2. $298 \mathrm{~s}$.

15. Grushko G.V., Linchenko S.N., Aleshin N.E. Aktual'nye aspekty problemy fuzarioza kolosa pshenicy i fuzariotoksinov na Kubani // Fundamental'nye issledovaniya. 2005. № 2. S.7 4-75. URL: https:// fundamental-research.ru/ru/article/view?id=5748

16. Yakuba G.V. Struktura patogennogo kompleksa vozbuditelej mikozov nazemnoj chasti rastenij yabloni v usloviyah izmeneniya klimata // Nauchnye trudy GNU SKZNIISiV. Tom 5. Krasnodar: GNU SKZNIISiV, 2014. S. 151-157.

17. Fuzarioz zernovyh kul'tur / T.Yu. Gagkaeva, O.P. Gavrilova, M.M. Levitin [i dr.]. // Zashchita i karantin rastenij. №5 (Prilozhenie). $51 \mathrm{~s}$.

18. Helgard, Kerrv, 1998. New Fusarium species and combinations within the Gibberella fujikuroi species complex. - Mycologia. - 90(3). p. 434-458.

19. Hassan N., Shimizu M., Hyakumachi M. (2014) Occurrence of root rot and vascular with diseases in Roselle (Hibiscus sabdariffa L.) in Upper Egypt / Naglaa Hassan, Masafumi Shimizu \& Mitsuro Yyakumachi Pages 66-72 / Received 19 Dec. 2013. Accepted 03 Feb. 2014, Published online: 19 Jun. 2018.

20. Brasier C. M. Phytophthora biodiversity: how many Phytophthora species are there? // Phytophthoras in Forests and Natural Ecosystems / Goheen E.M., Frankel S.J. (eds.). - Albany, CA, USA: USDA Forest Service, 2009. - P. 101-115. 